\title{
The Analysis of Teacher's Concern towards Study Innovation
}

\author{
$1^{\text {st }}$ Deitje Adolfien Katuuk \\ Departement of Elementary Schooler \\ Teacher \\ Universitas Negeri Manado \\ Manado, Indonesia \\ deitjekatuuk@unima.ac.id \\ $4^{\text {th }}$ Apeles Lexi Lonto \\ Pancasila and Civic Education \\ Department \\ Faculty of Social Science, Universitas \\ Negeri Manado, \\ North Sulawesi \\ Lexi.lonto@unima.ac.id
}

\author{
$2^{\text {nd }}$ Sjamsi Pasandaran \\ Pancasila and Civic Education \\ Department \\ Universitas Negeri Manado \\ Manado, Indonesia \\ spasandaran@unima.ac.id
}

\author{
$5^{\text {th }}$ Theodorus Pangalila \\ Pancasila and Civic Education \\ Department \\ Faculty of Social Science, Universitas \\ Negeri Manado, \\ North Sulawesi \\ theopangalila@unima.ac.id
}

\author{
$3^{\text {rd }}$ Recky Sendouw \\ State Administartion Department, \\ Faculty of Social Science, Universitas \\ Negeri Manado, \\ North Sulawesi \\ Manado, Indonesia \\ reckysendouw@unima.ac.id line
}

\begin{abstract}
This research aims to analyze the teacher's care profile toward study innovation, which is seen from teacher's characteristics either academic, competency and teaching experience. Using the quantitative approach with descriptive method. This research is undertaken towards 45 teachers in 15 elementary schools in Manado. Sample determination was purposely done. Questionnaire about the stage of teacher's concern was used in collecting the data. Data was analyzed by measuring the descriptive reliability and statistic. The research finding shows that there a variety of teacher's concern profile towards learning Innovation. The variety is related to the teacher's characteristics background whether in academic, competency or learning experience. The high stage of teacher's concern such as consequence, collaboration and refocusing was found on teachers that have the academic characteristics of teacher education, own the certification, and have five-year experience in teaching. It is recommended that the development of teacher's concern in learning innovation be brought about by concerning the characteristic of academic, competency and teacher's experience.
\end{abstract}

Keywords-concern stages, concern dimensions, teacher characteristic

\section{INTRODUCTION}

Education which closely relates to the learning innovation is one of the issues that has been investigated. The investigations were based on the weakness of effort in developing learning innovation in schools. It was found that the aspects of innovation management influence the fluency of school which includes the learning process such as leadership, the management of human resource [1]. The other finding is the weakness the tool utilization and technological form as innovation in learning [2]. Other investigation is about the implementation of innovative learning model such as integrated learning that can be executed in form of innovative student task [3]. It was also found that the factor of creativity and innovation in learning are relating one another. The development of learning innovation necessarily needs creativity [4]. Sadavel shows that the variety of student innovation and learning skill influence the learning development effort [5] Innovation in education, especially in learning, actually contributes someone's skill development and higher employability [6]. These findings investigate the determined factor issues towards the elaboration of learning innovation, types of model and forms of learning innovation, the implementation of innovative learning models, and the impact of learning innovation either in increasing school performance or academic performance. Even so, teacher psychological aspects have not found yet or still having lack of investigation especially teacher's concern in learning innovation. This research investigates the stage of teacher's concern towards earning innovation.

This research was done by using the quantitative approach, researched the stage of teacher's concern towards learning innovation. This research is beneficial to the elaboration of knowledge storage especially wider measurement aspect which is the concept of concern. To the decision maker such as headmaster, it is beneficial to be the advice framework for teachers. While to the teachers, it is beneficial to grow the awareness about the stage of concern towards learning innovation.

Study of educational innovation has been many times undertaken. A study by Romina shows the important implication of innovative teaching that can create or to boost students' creativity, but, on the other side, it needs the creative skill of the teacher in developing the innovation in learning process [7]. Currently, most of the researchers consider that technological mastery such as technological information and communication (ICT) by teachers, will lead to the innovative learning mastery [8]. While other researcher found that 
teachers in elaborating the innovative learning process, actually need the innovative environment. Education especially school is one of the working environments with a high level of innovation. The innovation can be in the form of a product or service, technology, tools, or instruments, and knowledge or methods [8]. Even so, there is an investigation that indicates the teacher's psychological aspect as the aspect in elaborating the innovative learning. The psychological aspect is the teacher's concern that can be gradually measured. Hui Zhang measures a teacher's stage of concern for media literacy education [9], While Gene E. Hall elaborates the measurement of the stage of teacher concern about an innovation [10].

The investigations about the stage of teacher's concern in education, are more describing about the characteristics and teacher's concern profile which can be understood as in which position the stage of teacher's concern is. A deeper analysis of the concerned aspects toward teacher's concern has not been done yet. This investigation, analyzes the relevance of teacher's stage of concern towards innovation by examining the aspects of teacher's understanding about the origin of innovation, innovation in education, teacher's attribute such as educational qualification, teaching experience, and the availability of supportive medium and infrastructure to the process of

innovation development in learning activity. Therefore, this investigation will enrich the comprehension and science knowledge about the relevance of teacher's stage of concern with wider aspects. As the model of investigation, this article can enrich the analysis models especially in the field of the stage of teacher's concern about innovation.

Analysis about teacher concern is generally based on the definition elaborated by Gene E. Hal, that defines teacher concern as "the composite representation of the feelings, preoccupation, thought, and consideration given to a particular issue or task [10]. Therefore, many researches were done pertaining to these particular issues such teacher's concern towards instructional technology [10], teacher's concern towards e-learning based [11], teacher's concern about inclusive education, and teacher's concern towards media literacy education [9] moreover in the learning outside of class context which is teacher's concern toward agriculture as learning context [12]. Variety of researches above are presented do depict the profile of concern towards particular varied issues as explained. Teacher's concern profile, is elaborated from Gene E. Hall's thought, and [13] divides into two categories which are the concern related to teachers themselves and their task, consist of the information stage (stage 1), personal stage (stage 2), and management stage (stage 3); and the concern in the highest level and points to the elaboration of innovation which are consequence stage (stage 4), collaboration stage (stage 5), and refocusing stage (stage 6) [13]. This research uses all of those seven stages elaborated by Gene E. Hall which stage 0: awareness, expresses there is no awareness of innovation, stage 1: information, expresses the longing of knowing the innovation, stage 2: personal, expresses the longing of knowing the effect of innovation on oneself, stage 3: management, expresses the longing to carry about the innovation, stage 4: consequence: expresses the longing to utilize the innovation, stage 5: collaboration, expresses the longing of working alongside with other to implement the innovation, stage 6: refocusing, a person that owns concept, new idea for a better innovation [14]. The stage of concern above shows the variety of feeling, thought, and longing of someone towards innovation.

The analysis of the teacher's concern towards innovation is relating to a teacher's background. It was found that teacher's relevant experience and the contextual factors are implicated to the stage of teacher's concern toward learning innovation [14]. Mikka finds that teacher's concern stage depicts the type of teacher, which is categorized as resistor, implementor, co-operator and over achievement [13]. Resistor teacher tends to resist innovation; implementer teacher shows high interest in innovation implementation. Cooperator type shows the availability to collaborate in implementing the innovation, while the over-achievement teacher indicates the strong desire for innovation. This research analyzes the teacher's concern profile towards learning innovation seen from the level of education, teaching experience, gender, and teacher's competency proven by teacher certification.

\section{RESEARCH METHODS}

This research uses the quantitative approach with descriptive method. The research was undertaken at 15 elementary schools in Manado, consist of 6 public schools and six private schools. Data source consists of 45 teachers, purposely chosen by considering the educational qualification, competency, and teaching experience. Research instrument is a questionnaire, divided into two parts; the first part is about teacher's attribute, and the second is about stages of teacher's concern (SoC) expanded from Gene E. Hall's framework which consists of stage 0 - awareness, stage 1 - information, stage 2 - personal, stage 4 - consequences, stage 5 collaboration, and stage 6 - refocusing. Data were analyzed by using the reliability analysis and descriptive statistic.

\section{RESULT AND DISCUSSION}

The profile of the teacher's concern towards innovation, which is the finding of this research, will be described in the following figures:

Research finding pictured in figure 1 shows that teachers who have the educational background, their stage of management, consequence, collaboration and refocusing are higher than those who do not have the educational background. The highest concern is on the stage of consequence, followed by the concern of management, collaboration and refocusing. Even so, it was also found that there was a teacher on the stage of awareness 


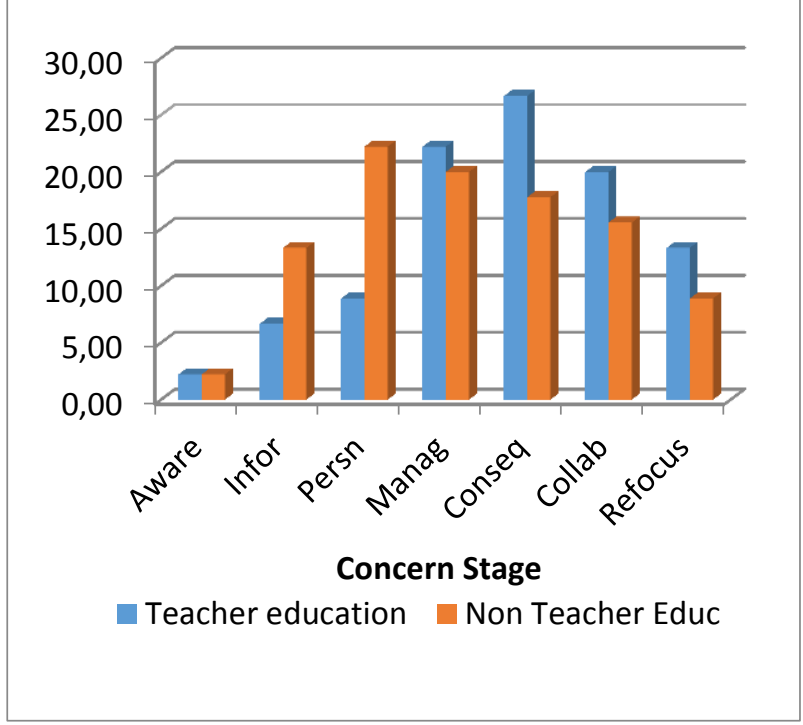

Figure 1 Percentage of teacher Concern Stage Based on Education

In figure 2, it shows that teachers that have teacher certification, owns the better level of concern towards learning innovation compared to those who do not yet have teacher certification. The certified teacher, the highest concern is on the stage of consequence and collaboration, followed by stage of management, and refocusing. While to those who do not have the certification yet, have the concern on the stage of personal, information followed by the stage of awareness.

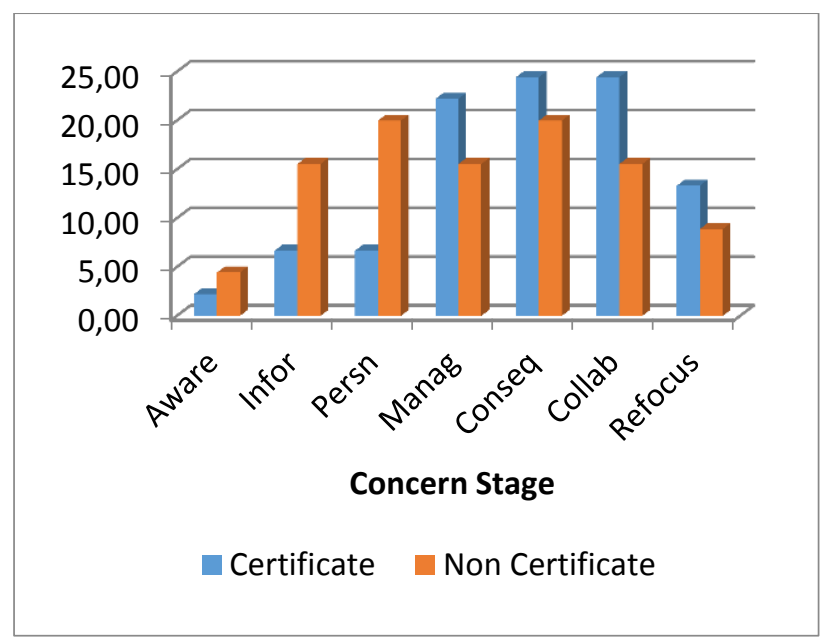

Figure 2 Percentage of teacher concern stage Based on Competence

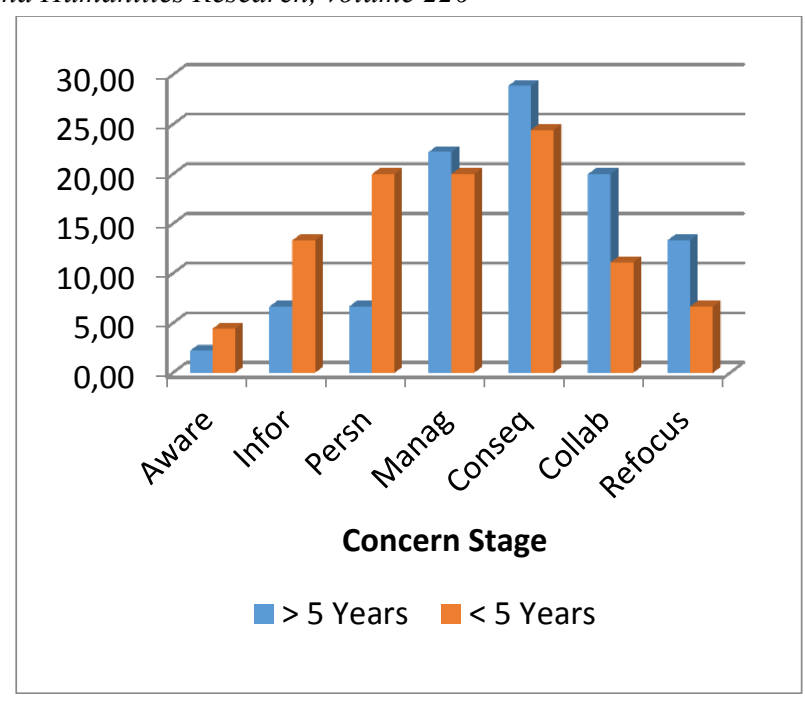

Figure 3 Percentage of teacher concern stage Based on Experience

In figure 3 , it pictures the concern stage of 5 teacher with more than 5-year experience in teaching is higher than those who have experienced less than 5 years. The highest stage of teachers with more than 5 year experience is on concern stage followed by a stage of management, collaboration and refocusing, while those who experienced less than five years have a high concern on personal stage, followed by the information stage, and there were teachers on awareness stage.

The level of teacher's concern toward the learning innovation on the stage of management, consequence, collaboration and refocusing shows that teachers have the strong dimension of concern on the task and impact dimension rather than self-dimension (Ahmad Mohammad Alshabatat, 2014) [11]. Task dimension indicates teachers concern towards the management aspect on the implementation of innovation, while the impact dimension indicates the reconditions caused by the innovation itself, team work concern in implementing the innovation, and concern to always embody the elaboration. Both of these strong dimensions depict that teacher have already had a strong concern on task, and the impact of innovation. It means that there is concern from teachers on the importance of innovation in elaborating the quality of learning process and result. The research finding shows the crucial position of teacher's dimensions of concern in implementing learning innovation besides innovative management factors [1], and the availability of media and infrastructure.

Dimensions of concern either self-dimension, task dimension or impact dimension seem influenced by the academic characteristic, competency and teacher's experience. The important academic characteristic is the educational background. So that the preparation of teacher through the teacher educational institute will become crucial. Competency characteristic means the teacher certification as the acknowledgement towards teacher's competency, while experience characteristic finds that the duration of teacher experience will reinforce the level of concern towards learning innovation.

\section{IV.CONCLUSION}

It can be concluded that there is concern from the teachers towards learning innovation. Varied concerns are 
based on the characteristic of academic, competency and teacher's experience. Teachers with teacher background, teacher certification as the competency acknowledgement and have more than 5 year experience in teaching do have high concern toward the learning innovation, and on the stages of management, consequence, collaboration, and refocusing while teachers with characteristic of academic, without teacher background, have no certification and less than 5 year experience do have the concern on the stages of personal and information. The stage of concern shows the strong dimension of teacher's concern on learning a task and the impact of innovation towards the enforcement of the learning process. Development and reinforcement of the dimension whether task dimension or impact dimension is important to be a reference of the development of teacher education either pre-service training or in-service training.

\section{ACKNOWLEDGMENT}

Thank you to Rector of Unima for facilitating the research funding through the institutional fund, thank you to researcher fellow, and Consortium ICJST for facilitating the publishment of this article.

\section{REFERENCES}

[1] J. Sitthisomjin, K. Somprach, and S. Phuseeorn, "The effects of innovation management on the school performance of secondary schools in Thailand," Kasetsart J. Soc. Sci., 2018.

[2] R. de Pablo Redondo, R. M. García, J. G. Arias, and R. A. Sanz, "Teaching Innovation Network: An educational virtual modell," Procedia-Social Behav. Sci., vol. 15, pp. 4053-4058, 2011.

[3] E. Barrios, A. López-Gutiérrez, and C. Lechuga, "Facing challenges in English Medium Instruction by engaging in an innovation project," Procedia-Social Behav. Sci., vol. 228, pp. 209-214, 2016.

[4] V. D. Opfer and D. Pedder, "Conceptualizing teacher professional learning,” Rev. Educ. Res., vol. 81, no. 3, pp. 376-407, 2011.

[5] T. Falch and C. Mang, "Innovations in education for better skills and higher employability," Eur. Expert Netw. Econ. Educ., 2015.

[6] R. Cachia, A. Ferrari, K. Ala-Mutka, and Y. Punie, "Creative learning and innovative teaching," Final Rep. study Creat. Innov. Educ. EU Memb. States, 2010

[7] G. V. S. Vally and K. Daud, "The implementation of school based management policy: an exploration," Procedia-Social Behav. Sci., vol. 172, pp. 693-700, 2015

[8] I. Peña-López, "Innovating Education and Educating for Innovation. The Power of Digital Technologies and Skills," 2016.

[9] H. Zhang, C. Zhu, and G. Sang, “Teachers' stages of concern for media literacy education and the integration of MLE in Chinese primary schools," Asia Pacific Educ. Rev., vol. 15, no. 3, pp. 459471, 2014.

[10] H. Casey and G. Rakes, "An analysis of teacher concerns towards instructional technology," Int. J. Educ. Technol., vol. 3, no. 1, 2002.

[11] A. M. Al-Shabatat, "Gifted'Teachers Stages of Concerns for Integrating E-Learning in the Gifted Schools in Jordan.," Turkish Online J. Educ. Technol., vol. 13, no. 2, pp. 79-87, 2014.

[12] K. A. Bellah and J. E. Dyer, "Attitudes and Stages of Concern of Elementary Teachers toward Agriculture as a Context for Teaching across Grade Level Content Area Standards.," J. Agric. Educ., vol. 50, no. 2, pp. 12-26, 2009.

[13] M. de Vocht, A. Laherto, and I. Parchmann, "Exploring teachers' concerns about bringing Responsible Research and Innovation to European science classrooms," J. Sci. Teacher Educ., vol. 28, no. 4, pp. 326-346, 2017.

[14] W. Wang, "Teachers' stages of concern and levels of use of curriculum innovation in China: A case study," Int. J. English Lang. Teach., vol. 1, no. 1, p. 22, 2013. 